\title{
Comparison of New Zealand perennial clovers for resilience against common pasture pests
}

\author{
P.J. Gerard ${ }^{1}$, C.M. Ferguson ${ }^{2}$ and S. van Amsterdam ${ }^{1}$ \\ ${ }^{1}$ AgResearch, Ruakura Research Centre, Private Bag 3123, Hamilton 3240, New Zealand \\ ${ }^{2}$ AgResearch, Invermay Agricultural Centre, Private Bag 50034 Mosgiel 9053, New Zealand \\ Corresponding author: pip.gerard@agresearch.co.nz
}

\begin{abstract}
Clovers (Trifolium spp.) are vulnerable to a large number of invertebrate pests so pest resilience amongst 19 leading commercial or near release New Zealand-bred clover cultivars was compared. Laboratory feeding choice tests comparing foliage from the test clovers against Grasslands Kopu II as the standard confirmed that red clovers (T. pratense) were less preferred than white clovers (T. repens) by adult clover root weevil and clover flea. Grey field slug showed no preference between red and white clovers, with the white clover Grassland Prestige performing the best. Porina larvae had lowest weight gains on strawberry clover ( $T$. fragiferum). Subsequent tests using neonate greenheaded leafroller larvae and an artificial diet made with freeze-dried foliage from cultivars in the most and least preferred subgroups indicated antifeedant compounds, rather than leaf morphology, are likely responsible for differences in feeding preferences between red and white clovers.
\end{abstract}

Keywords white clover, red clover, strawberry clover, Sitona obsoletus, Sminthurus viridus, Deroceras reticulatum, Wiseana copularis.

\section{INTRODUCTION}

Trifolium species, in particular white clover (T. repens), play a major role in pastoral systems in New Zealand, primarily via nitrogen fixation and as a high-quality feed. However, white clover, the base legume in most pastures, is very vulnerable to a large number of invertebrate pests. The most well-known are nematodes (Meloidogyne spp. (root-knot nematodes), Heterodera spp. (cyst), and Pratylenchus spp. (lesion)), grass grub Costelytra giveni (formerly C. zealandica (Coleoptera: Scarabaeidae)), the grey field slug (Deroceras recticulatum), weevils (in particular clover root weevil Sitona obsoletus (formerly S. lepidus) and white fringed weevil Naupactus leucoloma (Coleoptera: Curculionidae)), porina ((Wiseana spp.) (Lepidoptera: Hepialidae)), black field cricket Teleogryllus commodus (Orthoptera Gryllidae) and clover flea Sminthurus viridus (Collembola: Sminthuridae). The diversity, composition and abundance of above- and below-ground pests varies from district to district. Therefore, clovers are under constant pressure and usually do not compete well against vigorous ryegrasses that are protected by insect-active alkaloids produced by fungal endophytes (Easton et al. 2001).

Pest resistance has been identified by plant breeders as a critical component to improve clover vigour and persistence (Woodfield \& Caradus 1996; Abberton \& Marshall 2005; Williams et al. 2007). However, breeding for clover pest 
resistance in New Zealand has been limited, mainly focusing on white clover resistance against nematodes e.g. root-knot nematodes (Mercer et al. 2000). Instead, breeders have selected for local adaption and generic persistence traits such as higher stolon growing point densities (Caradus \& Chapman 1996). The value of this approach was seen when New Zealand and USA ecotypes were compared in both countries in the 1990s and the locally adapted cultivars performed best in their respective countries (Widdup et al. 1996). There is great potential to introduce new genetic material into the local gene pool through crossing or hybridisation with Trifolium species with known resistance attributes (Jahufer et al. 2012). An example is the Caucasian $\times$ white hybrid Aberlasting that combines two resilience traits (stolons and rhizomes). However, the first step in improving pest resistance is assessing what generic pest resilience is present already in New Zealand in view of local agronomic advantages of New Zealand clovers.

Red clovers, commonly sown in summer dry areas, are known for their isoflavones, which act as defence compounds against herbivores and diseases. However, these oestrogenic compounds can impact on animal reproduction, and this has led to the development of red clover cultivars such as Grasslands Relish that have low levels of formononetin, the most problematic of the phytoestrogens. Some clovers are also cyanogenic i.e. capable of producing hydrogen cyanide $(\mathrm{HCN})$, which may act as a feeding deterrent.

This study reports on feeding assays undertaken in summer 2016/17 to screen 17 current commercial clover cultivars bred or used in New Zealand, and two near release New Zealandbred cultivars, for possible pest resistance. The invertebrates used in these assays represent four diverse groups (Coleoptera, Collembola, Gastropoda, Lepidoptera) and consist of both specialist and generalist herbivores, and exotic and indigenous species. These assays were part of a larger project that included pot trials, with the aim of identifying a subset of clover cultivars for subsequent testing for pest resilience under field conditions.

\section{MATERIALS AND METHODS Clover selection and cultivation}

Clover cultivars were selected for screening following consultation with clover breeders from the main New Zealand seed companies as well as AgResearch scientists involved in clover research, and reference to recent research (Ford \& Barrett 2011; Ferguson et al. 2016). These consisted of seven red clovers Trifolium pratense, 10 white clovers T. repens, a Caucasian (T. ambiguum) $\times$ white clover hybrid, and a strawberry clover Trifolium fragiferum (Table 1). All are regarded as pest tolerant and/or persistent, which is reflected in the prevalence of semi-prostrate or prostrate growth habits in the red clovers selected and the dominance of high stolon density amongst the white clovers.

At both the Ruakura and Invermay Research Centres (AgResearch), at least 20 plants from each cultivar were grown from seed in pots of commercial potting mix in a glasshouse in winter 2016. All plants were inoculated with rhizobia. Once the plants were well established, they were transferred outdoors where they were maintained for several months before use in assays. This procedure was to ensure plants were exposed to similar climatic conditions and some of the same biotic stresses as clovers in pastures. 
Table 1 Morphological and published phytochemical descriptions of nineteen clover cultivars selected for feeding assays to screen for possible pest resistance.

\begin{tabular}{|c|c|c|c|}
\hline $\begin{array}{l}\text { Clover type } \\
\text { and cultivar }\end{array}$ & Growth habit & Leaf size & $\begin{array}{l}\text { Phytochemistry } \\
\text { (if known) }\end{array}$ \\
\hline \multicolumn{4}{|l|}{ Red } \\
\hline Grasslands Relish & Semi-prostrate, tap root & Medium & Low isoflavone \\
\hline SF Rossi & Semi-prostrate, tap root & Large & Moderate isoflavone \\
\hline Rubitas & Stoloniferous prostrate & Large & \\
\hline Grasslands Sensation & Upright, tap root & Large & Moderate isoflavone \\
\hline SPTP $16001^{1}$ & Semi-prostrate, tap root & Medium & \\
\hline SPTP $16002^{1}$ & Semi-prostrate, tap root & Medium & \\
\hline Tuscan & Semi-prostrate, tap root & Medium & $\begin{array}{l}\text { Moderate-high } \\
\text { isaflovone }\end{array}$ \\
\hline \multicolumn{4}{|l|}{ White } \\
\hline Rivendel & High stolon density & Small & Moderate $\mathrm{HCN}^{2}$ \\
\hline SF Quest & High stolon density & Medium-large & \\
\hline Grasslands Mainstay & High stolon density & Large & \\
\hline Grasslands Kopu II & High stolon density & Large & Moderate $\mathrm{HCN}$ \\
\hline Grasslands Tribute & High stolon density & Medium-large & High HCN \\
\hline Quartz & High stolon density & Medium & \\
\hline Apex & High stolon density & Medium & High HCN \\
\hline Weka & High stolon density & Medium & \\
\hline Hilltop & High stolon density & Small-medium & \\
\hline Grasslands Prestige & High stolon density & Small-medium & Moderate HCN \\
\hline \multicolumn{4}{|l|}{ Caucasian $\times$ white } \\
\hline AberLasting & Stoloniferous, rhizomatous & Small & \\
\hline \multicolumn{4}{|l|}{ Strawberry } \\
\hline Palestine & Stoloniferous & Medium & low isoflavone \\
\hline
\end{tabular}

${ }^{1}$ Near to market but not yet commercially available

${ }^{2} \mathrm{HCN}=$ hydrogen cyanide

\section{Feeding preference assays with weevils, clover fleas and slugs}

The feeding preferences of three contrasting foliage feeding pests (clover root weevil adults, clover flea and grey field slug) on each of the cultivars were assessed in choice tests relative to the control cultivar Grasslands Kopu II at the Ruakura Research Centre. This cultivar was shown to be tolerant to clover root weevil soon after the pest established in New Zealand and as a consequence, has been included in later clover comparison research (e.g. Crush et al 2010; Ferguson et al. 2016). The invertebrates had been collected from pastures on the Ruakura Research farm and were maintained in cages on foliage from a mix of cultivars to try to prevent any acclimatisation to a particular clover.

For each assay, 9-cm Petri dishes were labelled and lined with moist filter paper, divided down the middle to separate test and control clover leaves. Leaves of a consistent size and age were cut from each of the test cultivars and a single leaf was placed on the test side of each Petri dish. A Grasslands Kopu II leaf of similar size and maturity was placed on the control side. Where the size difference was disparate between the test 
and control leaves, either leaflets were removed from trifoliates of large leaved test cultivars or additional leaves added for small leaved cultivars. Once the invertebrates were added, the Petri dishes were put in plastic containers lined with damp paper towels inside in a plastic bag to maintain humidity during the assay. All assays were run a controlled environment room set at $15^{\circ} \mathrm{C}$ and 16:8 L:D photoperiod.

The clover root weevil assay had a single adult weevil in each dish and was assessed at $48 \mathrm{~h}$ when the number of feeding notches on each leaflet was counted.

The clover flea assays had five large individuals per dish and was also assessed at $48 \mathrm{~h}$. The leaflets were scored on the visual estimate of percentage of the leaflet that had been eaten and the number of live clover fleas remaining was recorded.

Slugs were starved for 24-48 h before the assay to stimulate feeding. One mature slug was added to each dish. After $24 \mathrm{~h}$, leaves were visually assessed on percentage of each leaflet that had been eaten.

For each invertebrate, there were 20 replicate choice tests of each test clover paired with the standard (control) Grasslands Kopu II. The level of feeding (notches or leaf area) on the standard clover was subtracted from that on test clover in each replicate, and the mean difference is referred to as a 'preference index' from this point forward. A negative preference index indicated that the control was preferred over the test clover, and vice versa.

\section{No-choice assay with porina}

Adult female porina (Wiseana copularis (early flying (= southern) haplotype)), attracted to light at Allanton on the Taieri Plain, Otago, were collected on 8 November 2016. These were held individually overnight in $60-\mathrm{mL}$ specimen containers to collect eggs. The moths were subsequently identified to species by examination of the bursa copulatrix (Dugdale 1994). The eggs, and subsequent larvae, from each moth were kept separate throughout the experiment so that if any differences appeared between in breeding lines, this variation could be incorporated into statistical analyses. The eggs were surface sterilised (Carpenter 1983) and put on moist filter paper in $9-\mathrm{cm}$ Petri dishes in a controlled temperature room at $18^{\circ} \mathrm{C}$ to hatch. The same room was used for rearing the larvae. Immediately upon hatching, the larvae were transferred to $17 \times 19 \times 12 \mathrm{~cm}$ deep containers filled to a depth of $3 \mathrm{~cm}$ with potting mix that had been microwaved to kill resident mites and other invertebrates. Pieces of artificial Tahora white clover and carrot-based diet (Popay 2001) were placed on top of the potting mix before the larvae were introduced. As the larvae grew and consumed the diet, cut foliage of Tahora white clover was added to the containers. On 20 December, $5702^{\text {nd }}$ instar larvae were weighed individually and placed individually in 60$\mathrm{mL}$ containers half filled with potting mix and containing 1-3 leaves depending on leaf size of one of the 19 clover cultivars (Table 1, 30 replicates for each cultivar). Fresh leaves were provided approximately every 2 weeks to ensure larvae always had food available. The larvae were reared for 58 days $\left(6-7^{\text {th }}\right.$ instar) and weighed individually again on 16 February 2017 when survival was also assessed.

\section{Artificial diet no-choice assay with leafrollers}

This assay was carried out to elucidate what mechanisms may be responsible for differences found between clovers in the feeding preference assays weevils, fleas and slugs. The insect used here was greenheaded leafroller, Planotortrix octo, a minor clover pest that had performed well on the artificial diet, developing from neonate to mature larva in preliminary testing. The clovers used were SPTP 16001, SPTP 16002, Rubitas, Kopu II, Aberlasting and Weka and the in-house diet is one used regularly for ryegrass endophyte assays (Alison Popay, pers. comm.).

Clover cultivars in the most and least preferred subgroups from the assays were selected. For each clover, foliage collected from several plants was bulked by cultivar, freeze dried, ground into a fine powder, then incorporated into an artificial diet at the rate of $1.5 \mathrm{~g}$ of ground clover to $10 \mathrm{~g}$ of the stock diet. The diet was spread evenly in a $50-\mathrm{mm}$ 
labelled Petri dish and stored at $4^{\circ} \mathrm{C}$ until required.

For each cultivar, a plug of the diet/clover mix was placed in the base of 1.5-mL labelled microcentrifuge tubes along with a neonate greenheaded leafroller larva reared from eggs supplied by Plant and Food Research. There were 20 replicates for each clover. The tubes were placed in a rack, wrapped in tinfoil to block out light, and held in a controlled environment room at $20^{\circ} \mathrm{C}$. The vials were checked at $24 \mathrm{~h}$ to confirm larvae were alive and had commenced feeding. Larval survival, weight and head capsule width as measures of their development were assessed at 20 days.

\section{Statistical analyses}

Mixed model analyses as described by Upsdell (1994) were conducted on the preference index data to rank the order of preference for the test clover over Kopu II and to identify differences between and within clover species. The same analyses were carried out on the no-choice assay data (porina larval weight gain and greenheaded leafroller weight and head capsule width at 20 days). The data were graphed in order of estimated preference index and significant differences among individual cultivars are shown when the least significant intervals for the respective means do not overlap.

\section{RESULTS}

\section{Feeding preference assays}

The mixed model analyses determined that clover species was the dominant influence on feeding preferences of clover root weevil adults and clover flea and detected minimal differences within clover species between cultivars. The outcome of this was that the differences between cultivar estimated values within plant species were reduced compared to the raw preference index means (although the order or "ranking" of the cultivars remained). Clover root weevil adults and clover flea both showed similar strong differences in feeding preference indexes for white over red clover and no within-species cultivar preferences with the exception of cv. Grasslands Mainstay being preferred significantly less than cv. Weka by clover root weevil adults (Figure 1). Both invertebrates preferred strawberry clover and the hybrid Aberlasting more than the red clovers, and strawberry clover less than white clovers (Figure 1).

In contrast, clover species had no overall influence on grey field slug feeding preferences (Figure 1c) although cultivar differences were observed. Grasslands Prestige, a white clover, was least preferred, having a significantly lower preference index estimation than the five clovers provided with the highest estimations using the mixed-model analysis.
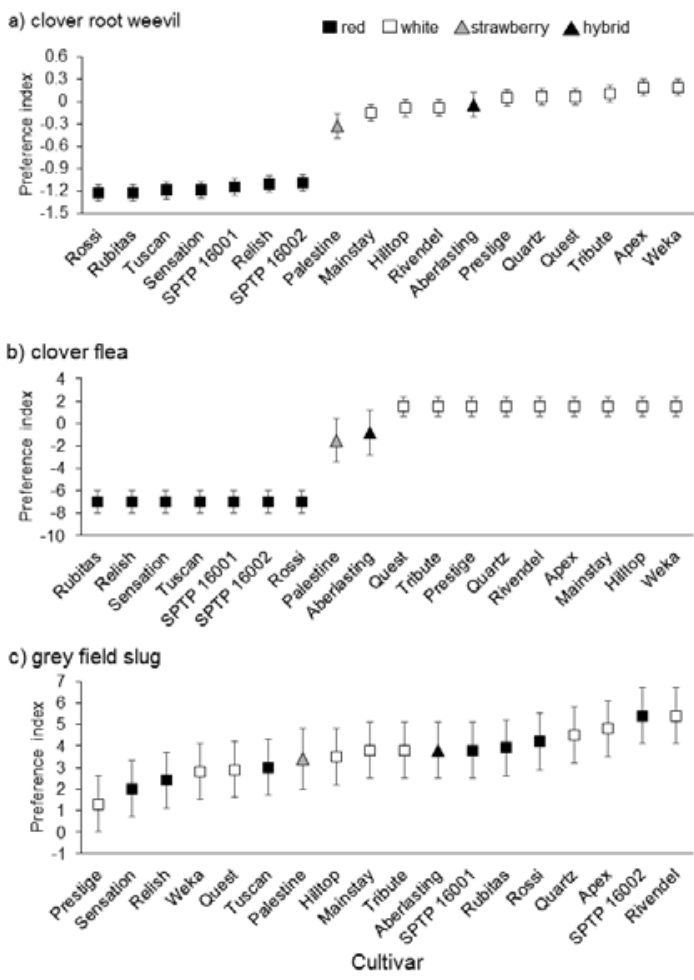

Figure 1 Mixed model ranking of feeding preference indices relative to Grasslands Kopu II of three invertebrates on 18 clovers relative to Kopu II. Clover root weevil adult preferences were assessed on leaf notches/leaf and clover flea and grey field slug by \% leaf area damaged. Error bars denote least significant intervals with no overlap indicating significant differences. 
There was no significant impact of clover species or cultivar on invertebrate mortality and generally mortality was low during these assays $(0.8 \%$ clover root weevil, $4.8 \%$ clover flea, $0.2 \%$ slugs).

\section{No-choice assay with porina}

The mixed model analysis showed that porina larvae gained significantly more weight on red clover cultivars than either white or Aberlasting $(\mathrm{P}<0.05)$ which, in turn, were higher than on strawberry clover $(\mathrm{P}<0.05)$. There were no significant cultivar differences within clover species, or any clover cultivar or species effect on the $3 \%$ larval mortality during the experiment. However, there was some overlap of species with the actual means (Figure 2), and only strawberry clover showed a marked deleterious effect on larval weight gain.

\section{No-choice assay with leafrollers}

Greenheaded leafroller larvae had significantly lower weights and head capsule sizes on the three red clovers in the assay compared with the two white clovers. Performance on hybrid cv. Aberlasting was intermediate between red and white clovers (Figure 3). There were no significant cultivar effects relating to the $15 \%$ larval mortality during the experiment.

\section{DISCUSSION}

The feeding preferences of the specialist legume feeders (clover root weevil adults and clover flea) were very similar to each other. However, these were quite different to that of the generalist grey field slug. Also, clovers produced a different effect on development of the endemic porina, which feeds on a wide range of native and introduced grasses and legumes, (Farrell et al. 1974; Atijegbe

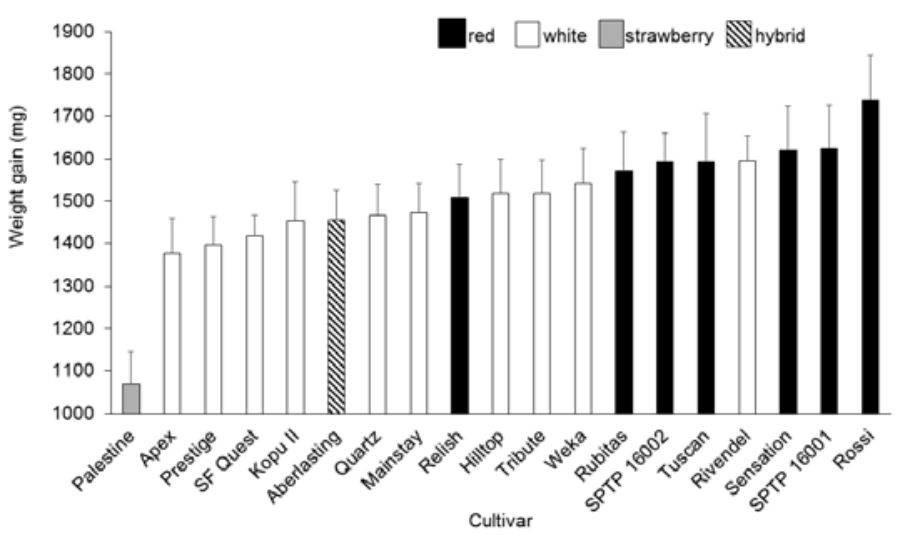

Figure 2 Effects of different clovers cultivars on mean weight gains by porina larvae. Error bars denote standard error of the mean.

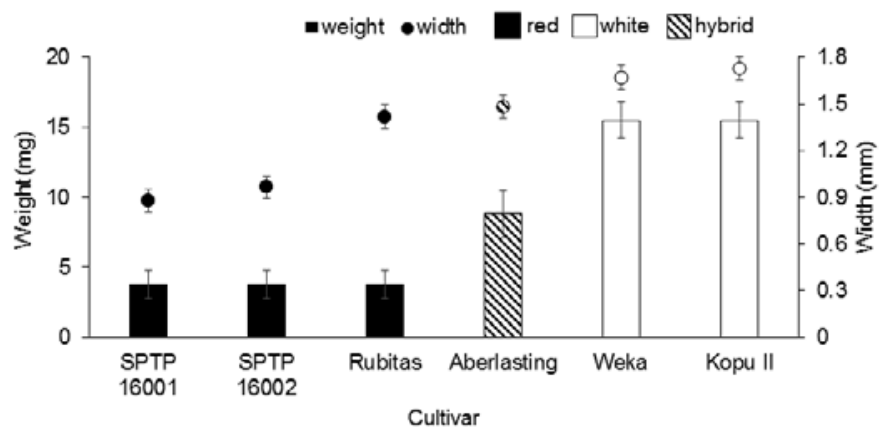

Figure 3 Estimated effects from mixed model analysis of six clover cultivars on greenheaded leafroller larval weight and head capsule width at 20 days. Error bars denote least significant intervals, with no overlap indicating significant differences. 
et al. 2016). These results possibly reflect the co-evolution of specialist pests and clovers and/ or whether clover defence mechanisms were retained during clover selection and breeding for agriculture.

The results from the feeding assays showing clover root weevil adults preferred white over red clover confirm previous experimental results using only single cultivars of each clover species (Murray \& Clements 1994; Gerard et al. 2005). They also align with field observations that more clover root weevil adults are found on white clover plants than on red (Ferguson et al. 2016). Similarly, the results also support field observations by Cooper (1994) who found less clover flea damage to red clover cultivars than white clovers.

There was no evidence from these assays that clovers with low levels of formononetin (e.g. Grasslands Relish) had higher feeding damage estimators than SF Rossi, Grasslands Sensation or Tuscan, three red clovers with moderate levels of formononetin (Table 1). While the results are promising, the factors which give rise to preferential feeding by pests are still unknown.

There is some evidence that cyanogenesis in white clovers may help deter molluscs (Dirzo \& Harper 1982), but it was not the case not in this study. Apex, a high cyanogenic clover, had significantly higher damage by grey field slug than Grasslands Prestige, a clover with moderate cyanogenesis capability. Deroceras recticulatum can adapt to elevated hydrogen cyanide potential (Burgess and Ennos 1987) and the slugs used in these assays were collected from the field so they would have been exposed to moderate to high cyanogenic clovers. Brooks et al. (2003) reported slug feeding differences between a single unknown white and an unknown red cultivar but no species preference was apparent in this study. Deroceras reticulatum has a documented host range of several hundred plants (Godan 1983) suggesting considerable plasticity in dealing with plant defences so significant differences within a single genera could be considered unlikely.

The native food plants of porina are not definitively known but Atijegbe et al. (2016) indicated that, potentially at least, a wide range of grasses could have formed part of their diet. It is not surprising then that intra-species differences of white and red clovers are not expressed in differing development rates of porina, given that porina exploit numerous introduced exotic pastoral grass and legume species. However, that observation does make the markedly poor performance of porina on strawberry clover more significant, and elucidation of why that is may be useful in developing porina-resistant clovers. Strawberry clover is marketed by seed suppliers as relatively tolerant to pests compared with most domesticated clovers. As yet the resilience mechanism is of strawberry clover is unknown but it has a low isoflavone content so that is not the reason.

The artificial diet assay with greenheaded leafroller was carried out to understand better the possible mechanisms underlying the differences found among clover species for other pest species. Large differences were found between red and white clover in larval growth but none in mortality. By using the artificial diet, plant morphology can be excluded as a factor in this case. Micro structures such as phytoliths may still have an impact on feeding but if they indeed differ between clover species this was not apparent in the porina assay. The survival data suggest that acute toxins or moulting disruptors are unlikely to be responsible for the different growth rates and the porina results suggest nutritive quality differences between red and white clovers are unlikely to be a factor although this cannot be ruled out for strawberry clover. This leaves antifeedants as the most likely mechanisms worthy of further investigations.

In conclusion, this study demonstrated that clover species rather than cultivar is responsible for the biggest differences in invertebrate/foliage herbivore interactions although the reasons for observed differences are not yet known. Unfortunately, tap-rooted red clovers have relatively poor persistence in pasture grazed by cattle (Ford et al. 2011) so plant breeders must balance agronomic as well as pest resilience factors in their search for more persistent clovers. If we are to improve the ability of the two main New 
Zealand clover species to cope with pest attack, it appears that novel genetic material would need to be sourced from outside current New Zealand cultivars by crossing or hybridising with clovers with known resistance attributes. If the factors differentiating white and red clover attractiveness to clover root weevil adults and clover flea can be identified, breeders can use this knowledge to improve the resilience of white clover against those pests. In the case of porina, a significant long-term intractable pasture pest, such genetic material may exist with strawberry clover.

\section{ACKNOWLEDGEMENTS}

The authors wish to thank Anne Barrington for supply of greenheaded leafroller eggs, Martin Upsdell for the statistical analyses and Diane Barton and Rachel Macdonald for assistance with the porina bioassay.

This project was funded by DairyNZ (Project BP 1504). Seed was supplied by Agriseeds, Agricom, Germinal Seeds, Kiwi Seed Company, PGG Wrightsons Seeds and Seed Force. A summer studentship for Sarah van Amsterdam was partially supported by Agriseeds.

\section{REFERENCES}

Abberton MT, Marshall AH 2005. Progress in breeding perennial clovers for temperate agriculture. Journal of Agricultural Science 143: 117-135.

Atijegbe SR, Mansfield S, Rostas M, Worner S, Ferguson CM 2016. Growth rate, survival and preference of porina (Wiseana spp.) to selected grasses. New Zealand Plant Protection 69: 326.

Brooks AS, Crook MJ, Wilcox A, Cook RT 2003. A laboratory evaluation of the palatability of legumes to the field slug, Deroceras reticulatum Muller. Pest Management Science 59: 245-251.

Burgess RSL, Ennos RA. 1987. Selective grazing of acyanogenic white clover: Variation in behaviour amoung populations of the slug Deroceras reticulatum. Oecologia 73. 432-435.
Caradus JR, Chapman DF 1996. Selection for and heritability of stolon characteristics in two cultivars of white clover. Crop Science 36: 900-904.

Carpenter A, 1983. Chemical treatment of porina eggs to prevent loss of viability in culture. New Zealand Entomologist 7: 466-467.

Cooper BM 1994. Screening a range of white clover and two red clover lines for relative tolerance to clover flea. Proceedings of the Forty-seventh New Zealand Plant Protection Conference 47: 287-288.

Crush JR, Gerard PJ, Ouyang L, Cooper BM, Cousins G 2010. Effect of clover root weevil larval feedingon growth of clover progenies from parents selected for tolerance in field trials. New Zealand Journal of Agricultural Research 53: 227-234.

Dirzo R, Harper JL 1982. Experimental studies on slug-plant interactions. III. Differences in the acceptability of individual plants of Trifolium repens to slugs and snails. Journal of Ecology 70: 101-117.

Dugdale JS 1994. Hepialidae (Insecta: Lepidoptera). Fauna of New Zealand. Auckland, DSIR Plant Protection, Mt Albert Research Centre. Pp. 155.

Easton HS, Christensen M, Eerens JPJ, Fletcher LR, Hume DE, Keogh RG, Lane GA, Latch GCM, Pennell CGL, Popay AJ, Rolston MP, Sutherland BL, Tapper B 2001. Ryegrass endophyte: a New Zealand grassland success story. Proceedings of the New Zealand Grassland Association 63:37-46

Farrell JAK, Sweney WJ, Jones AE 1974. Plant resistance to the porina caterpillar Wiseana cervinata (Lepidoptera: Hepialidae). I. Resistance in legumes and grasses. New Zealand Journal of Agricultural Research 17: 373-378.

Ferguson CM, Barton DM, Philip BA 2016. Clover root weevil tolerance of clover cultivars. Journal of New Zealand Grasslands 78: 197-202.

Ford JL, Barrett BA 2011. Improving red clover persistence under grazing. Proceedings of the New Zealand Grassland Association 73:119124. 
Gerard PJ, Crush JR, Hackell DL 2005. Interaction between Sitona lepidus and red clover lines selected for formononetin content. Annals of Applied Biology 147: 173-181.

Godan S. 1983. Pest Slugs and Snails: Biology and Control. Springer-Verlag, Berlin, Heidelberg. $448 \mathrm{p}$

Jahufer MZZ, Ford JL, Widdup KH, Harris C, Cousins G, Ayres JF, Lane LA, Hofmann RW, Ballizany WL, Mercer CF, Crush JR, Williams WM, Woodfield DR, Barrett BA 2012. Improving white clover for Australasia. Crop and Pasture Science 63: 739-745.

Mercer CF, Van Den Bosch J, Miller KJ 2000. Progress in recurrent selection and in crossing cultivars with white clover resistant to the clover root-knot nematode Meloidogyne trifoliophila. New Zealand Journal of Agricultural Research 43: 41-48.

Murray PJ, Clements RO 1994. Investigations of the host feeding preferences of Sitona weevils found commonly on white clover (Trifolium repens) in the UK. Entomologia Experimentalis et Applicata 71: 73-79.
Popay AJ 2001. A laboratory rearing method for porina. New Zealand Plant Protection 54:251

Upsdell MP 1994. Bayesian smoothers as an extension of non-linear regression. New Zealand Statistician 29: 66-81.

Widdup KH, Caradus JR, Green J, Mueller JP, Pennell CP 1996. White clover ecotype germplasm from the USA for development of New Zealand and overseas cultivars. In: Woodfield DR ed. White clover: New Zealand's competitive edge. New Zealand Grassland Association Grassland Research and Practice Series 6, Christchurch. Pp. 149-153.

Williams WM, Easton HS, Jones CS 2007. Future options and targets for pasture plant breeding in New Zealand. New Zealand Journal of Agricultural Research 50: 223-248.

Woodfield DR, Caradus JR 1996. Factors affecting white clover persistence in New Zealand pastures. Proceedings of the New Zealand Grassland Association 58: 229-235. 